\title{
Rat postnatal prostate development is impaired by in vitro high-glucose environment
}

\author{
Isabella Silva Cassimiroํ, Amanda Rodrigues Cruz ${ }^{1}$, Beatriz Pelegrini Bosque ${ }^{1}$, \\ Laura Calazans de Melo Gomes ${ }^{1}$, Renata Graciele Zanon², Jéssica Regina da Costa Silva ${ }^{3}$, \\ Patrícia Tieme Fujimura ${ }^{3}$, Carlos Ueira-Vieira ${ }^{3}$ and Daniele Lisboa Ribeiro ${ }^{1}$ \\ ${ }^{1}$ Department of Cell Biology, Histology and Embriology, Institute of Biomedical Sciences - ICBIM, Federal University \\ of Uberlândia, Uberlândia, Minas Gerai, Brazil, ${ }^{2}$ Department of Anatomy, Institute of Biomedical Sciences - ICBIM, \\ Federal University of Uberlândia, Uberlândia, Minas Gerai, Brazil and ${ }^{3}$ Laboratory of Genetics, Institute of \\ Biotechnology, Federal University of Uberlandia, Uberlândia, Minas Gerai, Brazil
}

Correspondence should be addressed to D L Ribeiro; Email: daniele.ribeiro@icbim.ufu.br

\begin{abstract}
The prostate development has an important postnatal period where cell proliferation begins at the first days after birth and is related to gland growth and ramification. Any metabolic and/or hormonal changes occurring during the postnatal period can interfere with prostate branching. Hyperglycemia is a common condition in low-weight preterm babies at neonatal period and also a disorder found in the offspring of obese mothers. Thus, this study aimed to investigate the in vitro effects of a glucose-rich environment during prostate postnatal development. Wistar rats prostate were removed at birth and cultured for 1, 2 and 3 days in DMEM under normal $(5.5 \mathrm{mM})$ or elevated $(7$ and $25 \mathrm{mM})$ glucose concentrations. Samples were processed for morphological analysis, PCNA and smooth muscle $\alpha$-actin immunohistochemistry, evaluation of active caspase-3, ERK1/2 and Wnt5a gene expression. High glucose concentrations reduced the number of prostatic buds and proliferating cells. The natural increase in smooth muscle cells and collagen deposition observed in control prostates during the first 3 days of development was reduced by elevated glucose concentrations. The amount of active caspase- 3 was higher in prostates incubated at $7 \mathrm{mM}$ and TGF- $\beta$ levels also increased sharply after both glucose concentrations. Additionally, high glucose environment decreased ERK 1/2 activation and increased Wnt5a expression. These data show that high levels of glucose during the first postnatal days affected prostate development by inhibiting cell proliferation which impairs bud branching and this was associated with anti-proliferative signals such as decreased ERK1/2 activation and increased Wnt5a expression.

Reproduction (2020) $160469-480$
\end{abstract}

\section{Introduction}

Early prostatic development occurs in the pre-budding stage from the urogenital sinus around the 13th day after conception in rodents and between 8 and 9 weeks of gestation in humans (Bruni-Cardoso et al. 2008, Cunha et al. 2018). However, important postnatal events impact the final development of the gland (Hayward \& Cunha 2000, Bruni-Cardoso \& Carvalho 2007). Postnatal development includes epithelial growth, branching and ductal formation (Sugimura et al. 1986). Vilamaior et al. (2006) reported that there is an initial prostate growth after birth and, at the same time, an increase in gland weight. Then, there is a quiescent period between the fourth and sixth weeks, in which prostate growth is proportional to body growth, with the growth restarting in the seventh week until the adult phase. In this scenario, any metabolic and/or hormonal changes occurring during the postnatal period can interfere with prostate development.
Different studies have shown that the offspring of obese mothers fed a high-fat diet present blood glucose levels above normal during the first postnatal weeks and in adulthood (Pinto-Fochi et al. 2016, Pytlowanciv et al. 2016, Korsmo et al. 2020). Epidemiological data about maternal obesity are very scarce, but the surveillance of women of reproductive age offers some insights. Current estimates suggest that more than $21 \%$ of women in the world will be obese by 2025 and this condition may negatively impact glucose levels of offspring (Poston et al. 2016). In addition, neonatal hyperglycemia is one of the most common metabolic abnormalities encountered in preterm newborns, ocurring 3-5 days after birth (Rozance \& Hay 2010). Hyperglycemia in the neonatal period may develop as a result of various mechanisms including iatrogenic causes, inability to supress hepatic glucose production, insulin resistance or glucose intolerance (Şimşek et al. 2018, Ramel \& Rao 2020). During the first postnatal week, about 
one-third of very low-birth-weight infants have glucose concentration of $>120-180 \mathrm{mg} / \mathrm{dL} \quad(6.6-10 \mathrm{mmol} / \mathrm{L})$ (Zamir et al. 2018). Considering the possibility of individuals being born hyperglycemic, the knowledge about the effects of glucose during the first postnatal days (period of intense epithelial growth and glandular ramification) in the prostate development is essential to establish preventive strategies.

Many studies have highlighted the effect of hyperglycemia-related disorders on the prostate. Studies conducted by our research group showed that diabetes and obesity affect cell proliferation and promote ventral prostate atrophy in adult mice, suggesting that prostate function is influenced by high glucose and reduced testosterone levels (Ribeiro et al. 2009, 2012, Arcolino et al. 2010, Gobbo et al. 2012). Furthermore, Damasceno et al. (2014) demonstrated that maternal diabetes caused mild hyperglycemia and reduced the ventral prostate weight of offspring. Although none of them are models for studying the direct effects of glucose on the gland development, these investigations elucidate that prostate responds and can be affected by high glucose levels and also that the mother's hyperglycemia continues to affect the offspring's prostate at adulthood. However, it is not evident whether this impact is present from the early days of prostate postnatal development and if it is a direct effect of glucose or androgenic deficiency found in adult life. To the best of our knowledge, there is no study that assesses whether hyperglycemia at birth would affect the ramification of prostate epithelial buds that occurs in the first postnatal days. Such effects may have a negative impact on male reproduction at adult life and could be easily prevented through glycemic control.

Thus, this study aimed to evaluate the influence of different concentrations of glucose in vitro during the first postnatal days of prostate development. We found that high glucose treatment during 3 days of postnatal life reduced prostate branching through impaired cell proliferation which was associated to decrease in ERK1/2 activation and increased Wnt5a expression.

\section{Materials and methods}

\section{Animals and organ culture}

The animals were treated following the guidelines on ethics in the use of animals for biomedical experimentation and research of the National Council for Animal Experimentation Control (CONCEA); the project was approved by the Animal Experimentation Ethics Committee (CEUA-UFU) under the technical advice 110/16; 024/2019).

Ninety male Wistar rats from Rodent Bioterium Network (REBIR) of the Federal University of Uberlandia were decapitated at birth (day 0 ) and their ventral prostates were dissected under a stereoscopic microscope for magnification. The whole ventral prostate and its insertion into the urethra was cultured for 3 days on PTFE membranes (Millipore) floating under $500 \mu \mathrm{L}$ of basal medium consisting of low glucose DMEM/Ham's F-12 (1:1; vol:vol) supplemented with insulin-transferrin-selenium (Gibco) and $10 \mathrm{nM}$ testosterone cypionate (Novaquímica), according to the method described by Lopes et al. (1996). The prostates were divided in three groups, according to glucose concentration: control group $-5.5 \mathrm{mM}$ (treated with basal medium as described above, containing normal glucose levels - $100 \mathrm{mg} / \mathrm{dL}$ ); $7 \mathrm{mM}$ (representing moderate glucose levels; $125 \mathrm{mg} / \mathrm{dL}$ ); and $25 \mathrm{mM}$ (representing high glucose levels; $450 \mathrm{mg} / \mathrm{dL}$ ). Media were changed every $24 \mathrm{~h}$ and prostates were incubated for 1, 2 and 3 days after birth (Day 0). The prostates were photographed in an inverted microscope coupled to an imaging system after 3 days of culture. The entire prostate area was demarcated using Image Pro Plus software to determine the glandular area.

\section{Histological processing and morphometrical analysis}

The prostates were fixed by immersion in Bouin's fluid for $3 \mathrm{~h}$ under refrigeration, washed in water, dehydrated in ethanol series, clarified in xylol and embedded in paraffin for histological processing. Then, paraffin sections of prostate $(4 \mu \mathrm{m})$ were serially cut on a rotary microtome (Leica), selecting one section and discarding the next six, until the entire prostate was sectioned. Sections were stained with hematoxylin-eosin for general histoarchitecture studies and picrosirius red for the characterization of collagen deposition. The images were taken via a photomicroscope (Leica, DM500) coupled with an image acquisition system. The prostate cross equatorial sections stained in H\&E were used to evaluate the frequency of prostatic buds and mitotic figures, respectively. For this approach, slide number 10 of the serial histological sections was used for all groups, which represents the middle of the prostate in cross equatorial section. On this histological section, the total number of acinar buds and the number of mitoses within each bud were counted using the $10 x$ and $40 x$ lens, respectively. In this analysis, 7-10 histological sections per group were used ( $n=7-10$ animals/group). Thus, in brief, buds and mitoses were counted using 1 histological section per animal in each group, which represented the cross-section of the middle of the prostate.

Morphometrical measurements of prostate buds was performed using Image J (Rasband, W.S., ImageJ, U. S. National Institutes of Health, Bethesda, Maryland, USA, https://imagej. nih.gov/ij). The diameter of all prostatic bud cross-sectioned was measured in at least five histological sections per group.

For the estimation of collagen content, the sections stained by Picrosirius were submitted to stereological analysis. The percentage of collagen area was calculated by using the Weibel method of counting points (Weibel 1974), which consisted of a reticulum containing 100 points. Each point that touched collagen staining was considered. This histological analysis was performed on the prostate of five animals for each experimental period.

\section{Immunohistochemical reaction}

Paraffin sections were submitted to antigen retrieval in citrate buffer, $\mathrm{pH} 6.0$ at $92^{\circ} \mathrm{C}$ for $40 \mathrm{~min}$ and treated in $3 \%$ 
$\mathrm{H}_{2} \mathrm{O}_{2}$-methanol solution to block endogenous peroxidase. The elimination of unspecific binding was made by background sniper blocker (Biocare Medical, Concord, CA, USA) for $15 \mathrm{~min}$. Sections were incubated overnight at $4^{\circ} \mathrm{C}$ with the following primary antibodies: mouse anti-human $\alpha$-smooth muscle actin (sc-32,251, Santa Cruz Biotechnology) and mouse anti-human proliferating cell nuclear antigen (PCNA; mouse anti-human, sc-56, Santa Cruz Biotechnology). Both antibodies were diluted 1:100 in 1\% BSA. The sections were washed in PBST and incubated with Universal Link secondary antibody for $45 \mathrm{~min}$. The antigen-antibody complexes were detected by Streptavidin-HRP polymer (Star Trek Universal HRP Detection System-Biocare Kit). The reactions were revealed by diaminobenzidine - DAB (Biocare) and sections were counterstained with hematoxylin. The relative frequency of smooth muscle cells was determined using the Weibel's method described above. PCNA-positive cells were visually counted at 40× magnification, using ten microscopic fields from each histological section (4 animals, 40 microscopic fields per group).

\section{Western blotting}

For western blotting, day-3 prostate were analyzed. Each sample ( $n=3$ per group) was composed of a pool of 3-4 prostates. Prostate samples were homogenized at $4{ }^{\circ} \mathrm{C}$ in RIPA buffer (R0278, Sigma Aldrich) containing protease inhibitors (Protease Inhibitor Cocktail - Sigma Aldrich), centrifuged at 15,400 $\boldsymbol{g}$ and the supernatants were collected for protein quantification by Bradford method (Bradford 1976). Subsequently, aliquots containing $10 \mu \mathrm{g}$ of protein were separated by SDS-PAGE on $10 \%$ polyacrylamide TRIS-glycine gel and after electrophoresis, electroblotted upon nitrocellulose membranes. Nonspecific protein-binding sites were blocked with $5 \%$ albumin diluted in $0.2 \%$ TBST for $60 \mathrm{~min}$ at room temperature. Membranes were subsequently incubated overnight at $4{ }^{\circ} \mathrm{C}$ with primary antibodies diluted 1:1200 in $3 \%$ albumin in TBST (rabbit anti-human PERK \#4370; rabbit anti-human ERK, \#9102; mouse alpha tubulin anti-human \#3873 - Cell Signaling Technology). Subsequently, membranes were incubated with anti-rabbit HRP-conjugated IgG or antimouse HRP-conjugated IgGK diluted 1:35,000 in TBST for $1 \mathrm{~h}$. The immunoreactive components were detected by the ECL detection kit (GE HealthCare) and the chemiluminescence was detected in a photodocumentator Amersham Imager 600 (GE Healthcare Life Sciences). The densitometry of the protein bands was quantified by the Image J software (version 1.34; Wayne Rasband, Research Services Branch, National Institute of Health). The densitometry values of phosphorylated ERK 1/2 were normalized in relation to the total ERK $1 / 2$.

\section{Evaluation of apoptosis status}

Apoptosis was evaluated in day-3 prostate samples by the EnzCheck Caspase-3 Assay kit (Thermo Fisher), which quantifies caspase-3 levels in its active form. The caspase-3 content was expressed as fluorescence intensity normalized by the protein concentration in the sample. For each experimental group, 3 samples ( $n=3$ per group) were used, each containing a pool of 3-4 prostates. The samples were homogenized in Ripa buffer, using the protein extraction protocol previously described for Western blotting. The protein samples were $20 \times$ diluted in reagent buffer and incubated for $30 \mathrm{~min}$. The fluorescence (excitation/emission 342/441 nm) was measured in a microplate fluorimeter.

\section{TGF- $\beta$ quantification by ELISA}

The active form of TGF- $\beta$ in prostate extracts was measured by human/mouse TGF- $\beta 1$ Uncoated ELISA kit (\#88-8350 Invitrogen) according to the manufacturer's instructions, using $50 \mu \mathrm{L}$ of protein sample (1:5 sample:water). Briefly, samples were added to the ELISA plate previously coated with antiTGF- $\beta 1$ murine MAB. Then, biotinylated detection antibody and, subsequently, avidin-HRP complex were added. Finally, the plate was washed and the immunoreaction was revealed by tetramethylbenzidine (TMB) substrate. The TMB activity was interrupted by incubation with sulfuric acid $1 \mathrm{M}$ for $15 \mathrm{~min}$. Color intensity was measured at $450 \mathrm{~nm}$ on microplate spectrophotometer. For this approach, day 3 prostate were analyzed and each sample ( $n=3$ per group) was composed of a pool of 3-4 prostates.

\section{RNA extraction, reverse transcription, and real-time $q P C R$}

For gene expression analyses, 3-4 prostates on day 3 were pooled per sample replicate ( $n=3$ samples per group) for all groups. Total RNA was extracted from tissue samples using TRIzol (TRI reagent, Sigma Aldrich) following the manufacturer's protocol. Total RNA was treated with DNase (Promega) and quantified in a spectrophotometer (ND-1000, Thermo Fisher Scientific). From the DNase-treated RNA, $1 \mu \mathrm{g}$ was used as template RNA to synthesize first strand cDNA using M-MLV Reverse Transcriptase (Thermo Scientific) according to the manufacturer's instructions. Each $10 \mu \mathrm{L}$ RT-qPCR reaction mix consisted of $1 \mu \mathrm{L}$ of CDNA, $5 \mu \mathrm{L}$ of SYBRGreen ${ }^{\mathrm{TM}}$ PCR Master Mix (Applied Biosystems), 5 pmol of each primer and water. Amplification reactions were run in a Step One Plus Real-Time PCR System (Applied Biosystems) as follows: $95^{\circ} \mathrm{C}$ for $10 \mathrm{~min}$, and 40 cycles of $95^{\circ} \mathrm{C}$ for $15 \mathrm{~s}$ and $60^{\circ} \mathrm{C}$ for 20 s. A melting curve analysis was done to confirm specificity of the amplified product. The following primers were used: Wnt5a forward: 5'-TCGCCCAGGTTGTAATAGAAG-3' and reverse: 5'-TTGAGAAAGTCCCGCCAGTT-3'; Gapdh forward: 5'-AGACAGCCGCATCTTCTTGT-3' and reverse: 3'-TGTTCT TCTACGCCGACAGA-5'. The transcript levels of Wnt5A mRNA were calculated through the relative quantification method $2-\Delta \Delta C$ (Livak \& Schmittgen 2001). Wnt5a mRNA expression was normalized to the housekeeping gene Gapdh as a control.

\section{Statistical analysis}

All numerical data were tested for normal distribution using the Kolmogorov-Smirnov test. Experimental groups were compared by one- way ANOVA followed by Tukey

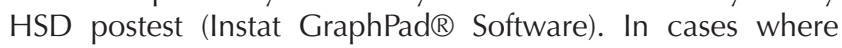
samples did not pass the normality test, the non-parametric 
Kruskal-Wallis test was used for groups comparisons. The threshold for significance was $P<0.05$.

\section{Results}

Glucose environment reduced prostate branching during the first 3 days of postnatal development

To assess the effect of high glucose on branching process during postnatal development, the prostate macroscopic area and the number of buds were measured. Considering the total area of the prostate, there was no difference between control or glucose-rich treatments after 3 days of postnatal gland development $(4.01 \pm 0.3 ; 4.13 \pm 0.5$; $4.12 \pm 0.4$ for $5.5 \mathrm{mM}, 7 \mathrm{mM}$ and $25 \mathrm{mM}$, respectively). On the other hand acinar bud branching is affected by elevated glucose concentrations (Figs $1 \mathrm{~A}$ and 2). On the first day of postnatal development, the normal glucose group presented about five acinar buds and this number increased progressively along the 3 days of development (Figs $1 \mathrm{~A}$ and 2A, B, C). However, in the 7 and $25 \mathrm{mM}$ glucose-treated groups, an opposite tendency is seen. There is a significant reduction in the number of buds, regardless of how high the glucose concentration is (Figs $1 \mathrm{~A}$ and $2 \mathrm{D}, \mathrm{E}, \mathrm{F}, \mathrm{G}, \mathrm{H}, \mathrm{I})$. Since the number of buds was decreased in high glucose groups, we counted the mitotic figures on each bud during microscopic evaluation to understand if cell proliferation would be related to this change. On the first and third days of development, the control group showed a large amount of mitosis. This pattern is not observed in glucose-rich environment-treated groups (Figs $1 \mathrm{~B}$ and 2). Although there is a satisfactory amount of mitotic figures on day 1 , the prostatic epithelial buds tended toward the absence of mitosis on the third day under $7 \mathrm{mM}$ glucose treatment. Across all 3 days of development, the $25 \mathrm{mM}$ group showed few mitotic figures (Figs 1B and 2).

Considering that the number of prostate buds and mitosis was influenced by glucose, we thought it would be interesting to perform a morphometrial evaluation to find out if this condition would also affect the volume of the epithelial area. At normal glucose conditions, in the first 3 postnatal days, during the prostate branching, together the increased number of buds there is also a reduction on their volume (Fig. 1C). However, under high glucose concentrations, the volume of prostatic buds is increased, especially on the third day of incubation, which is indicative of reduced bud ramification (Fig. 1C).

\section{Decreased prostate branching after high-glucose environment is related to reduced cell proliferation and increased apoptosis}

To validate the results on mitotic count and confirm if cell proliferation could be modulated by high glucose environment during prostate postnatal development, we performed immunhistochemistry for PCNA.
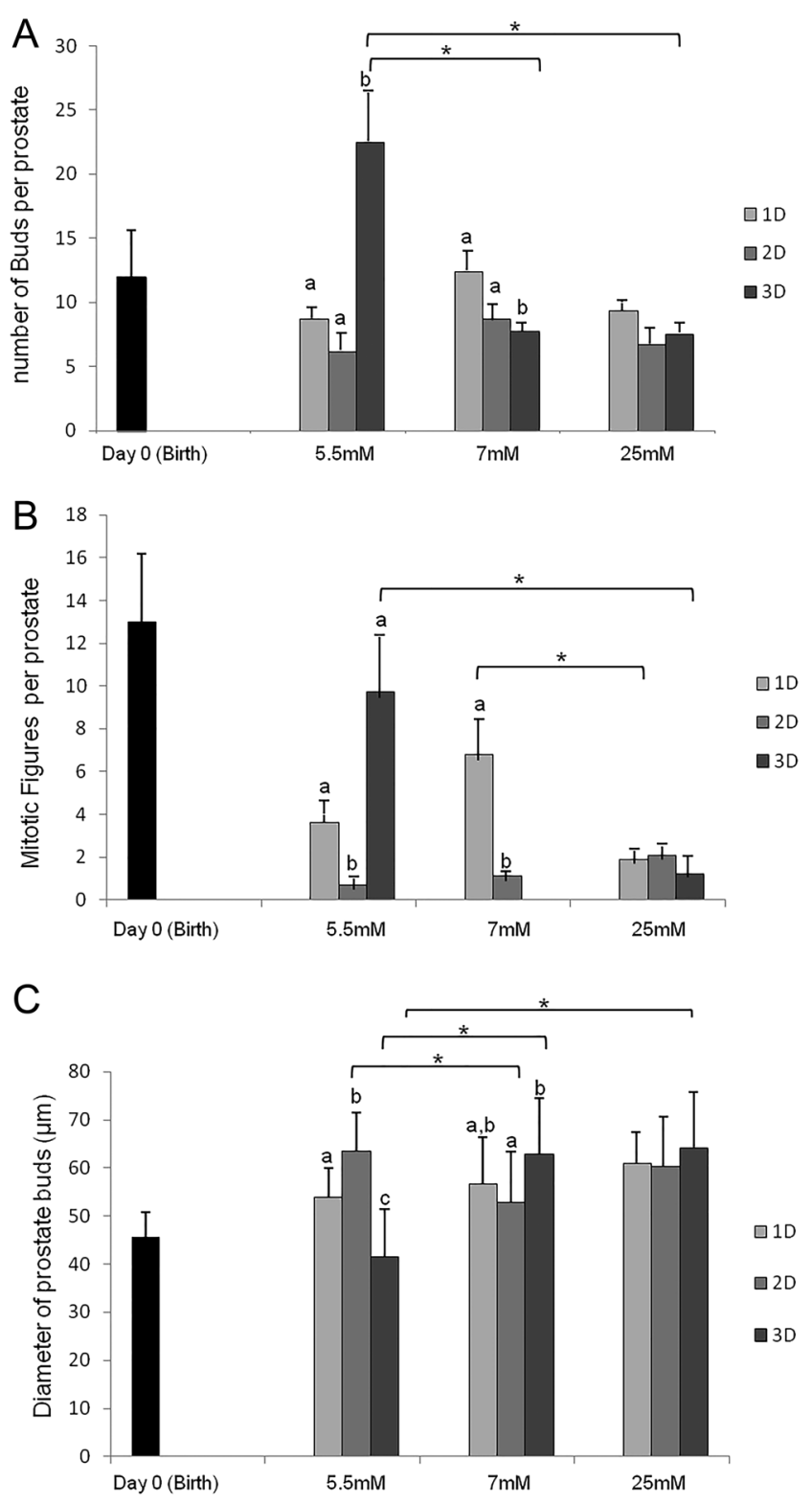

Figure 1 Glucose in high concentration affects prostate branching, mitosis and bud volume. Rat prostate was collected at birth (Day 0) and grown in media containing normal $(5.5 \mathrm{mM})$, moderate $(7 \mathrm{mM})$ or high $(25 \mathrm{mM})$ glucose concentration for 1, 2 and 3 days. Graphical representation of the number of prostate bud (A); the number of mitotic figures (B) and the diameter of bud (C). Average \pm S.D. of data obtained from each quantification (A, B $n=7-10 ; C n=5)$. a,b $P<0.05$ for time exposure; $* P<0.05$ versus normal glucose group.

This analysis revealed that, in normal glucose concentrations, the prostate epithelial and stromal cell proliferation increases until the third day of postnatal development (Fig. 3B, C, D, E and F). However, this pattern is modified at higher glucose concentrations. In the 7 and $25 \mathrm{mM}$ treated groups, there are a decreased number of proliferating cells, in both cell types, especially on the third day (Fig. 3B, C, $\mathrm{G}, \mathrm{H}, \mathrm{I}, \mathrm{J}, \mathrm{K}$ and $\mathrm{L}$ ). Regarding $25 \mathrm{mM}$, this reduction is 

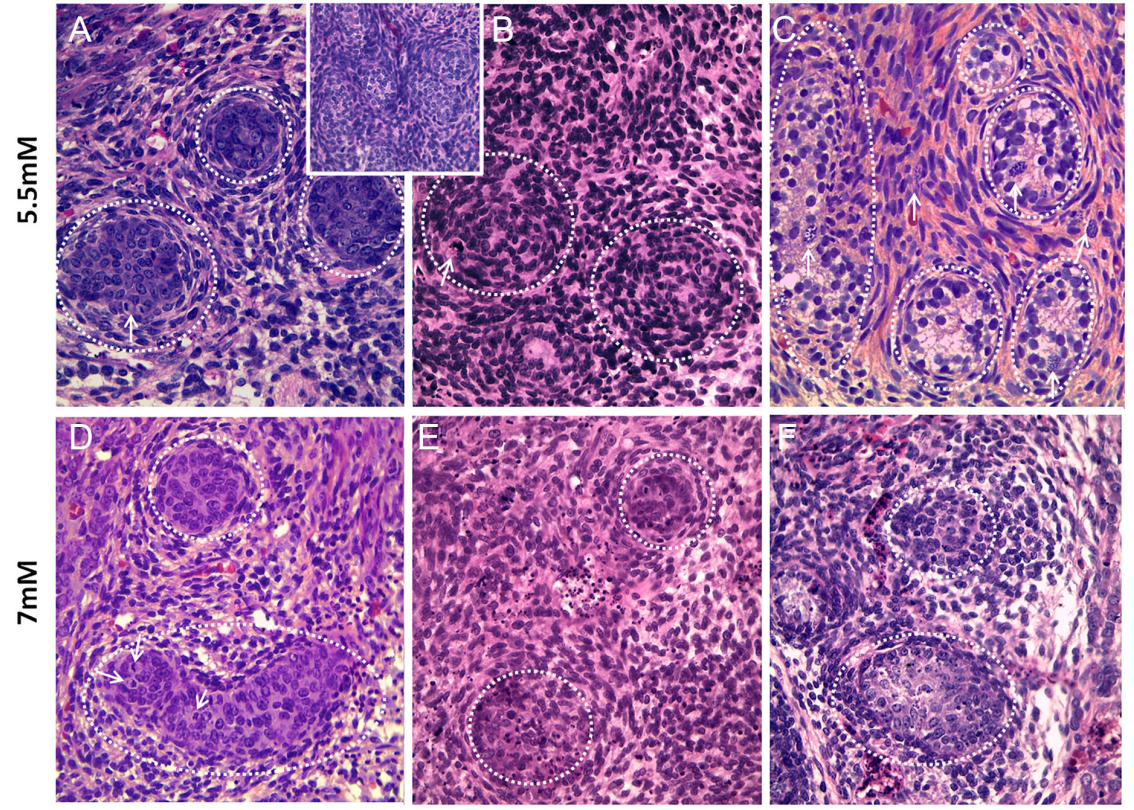

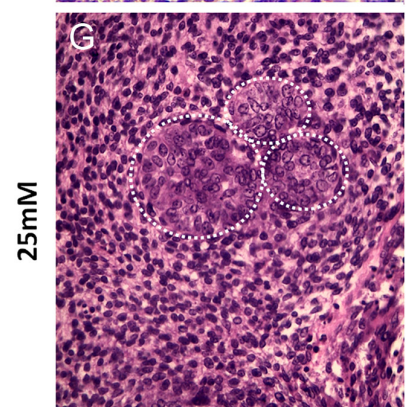

Day 1

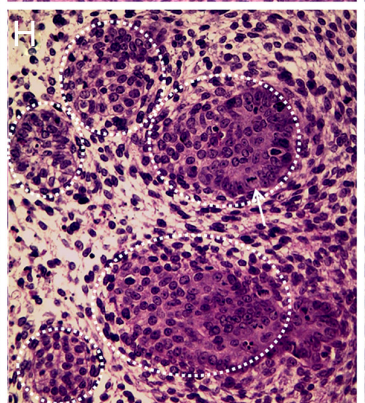

Day 2

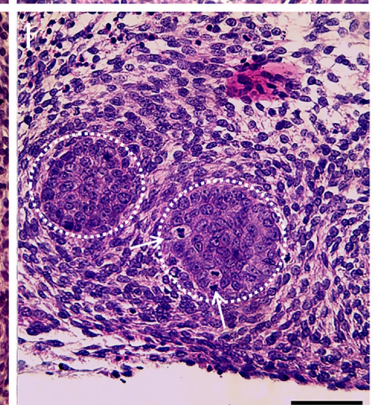

Day 3
Figure 2 Histological sections stained by hematoxylin and eosin of rat postnatal prostates grown in DMEM media containing normal (5.5 mM, A-C), $7 \mathrm{mM}(\mathrm{D}-\mathrm{F})$ and $25 \mathrm{mM}(\mathrm{G}-\mathrm{l})$ glucose concentrations on days 0 (inset), 1, 2 and 3 after birth. The frequency of prostate epithelial buds (dotted circles) and also mitotic figures (arrows) is reduced after glucose-rich treatment. Scale bar: $50 \mu \mathrm{m}$. significant from the first day of postnatal development (Fig. 3B and C).

Besides cell proliferation, apoptosis profile was also studied by measuring active caspase- 3 to analyze if this activity could impact prostate bud branching under high glucose treatment. This approach showed that only treatment with glucose at $7 \mathrm{mM}$ concentration led to an increase in the rate of apoptosis compared to control (Fig. 4A).

\section{Elevated glucose treatment modifies postnatal prostate stroma by reducing smooth muscle cell number and organization, collagen deposition and increasing TGF- $\beta$ levels}

In addition to prostate epithelial evaluation, this investigation studied whether the glucose-rich environment would also impact on the stromal organization by analyzing immunohistochemistry for smooth muscle alpha-actin and the deposition of collagen through Picrosirius staining. In the control group, from birth (day 0) to the first day of postnatal development, there is an increase in the prostate content of smooth muscle cells that remains elevated until the third day (Fig. 5A, B, C, D and E). This pattern is modified in 7 and $25 \mathrm{mM}$ glucose-treated groups, since there is a reduction in the expression of $\alpha$-actin in both glucose environments from the first day of postnatal development. Although there was a tendency to increase the content of $\alpha$-actin during the 3 days of treatments, the amount of smooth muscle cells was considerably lower than the expected for this period (Fig. 5B, F, G, $\mathrm{H}, \mathrm{I}, \mathrm{J}$ and $\mathrm{K}$ ). Similarly, at the interacinar stroma, from 1 to 3 days of postnatal prostate development, there is a natural increase in collagen deposition (Fig. 6A, $\mathrm{B}, \mathrm{C}, \mathrm{D}$ and E). However, after the $7 \mathrm{mM}$ treatment, a significant collagen reduction was observed from 1 to 3 days of postnatal development; under higher glucose concentrations, the decrease was only noted after the third day (Fig. 6B, F, G, H, I, J and K).

Considering the stromal effects caused by glucose-rich environment, we evaluated the prostate levels of TGF- $\beta$ to understand if this pro-fibrotic growth factor could be associated to reduced collagen deposition. We found that treatments with glucose at high concentrations elevated prostatic TGF- $\beta$ levels on the third day of postnatal development, being three-fold greater than control (Fig. 4B). 


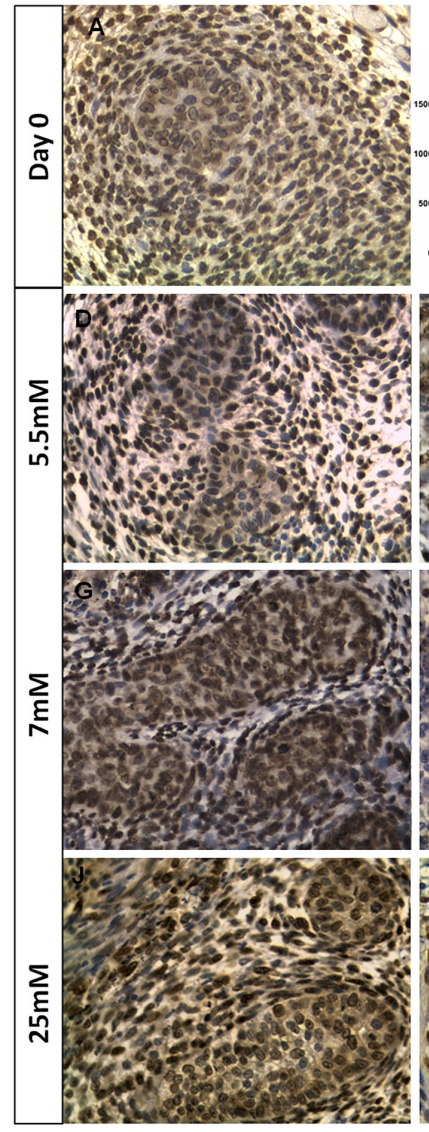

Day 1
B
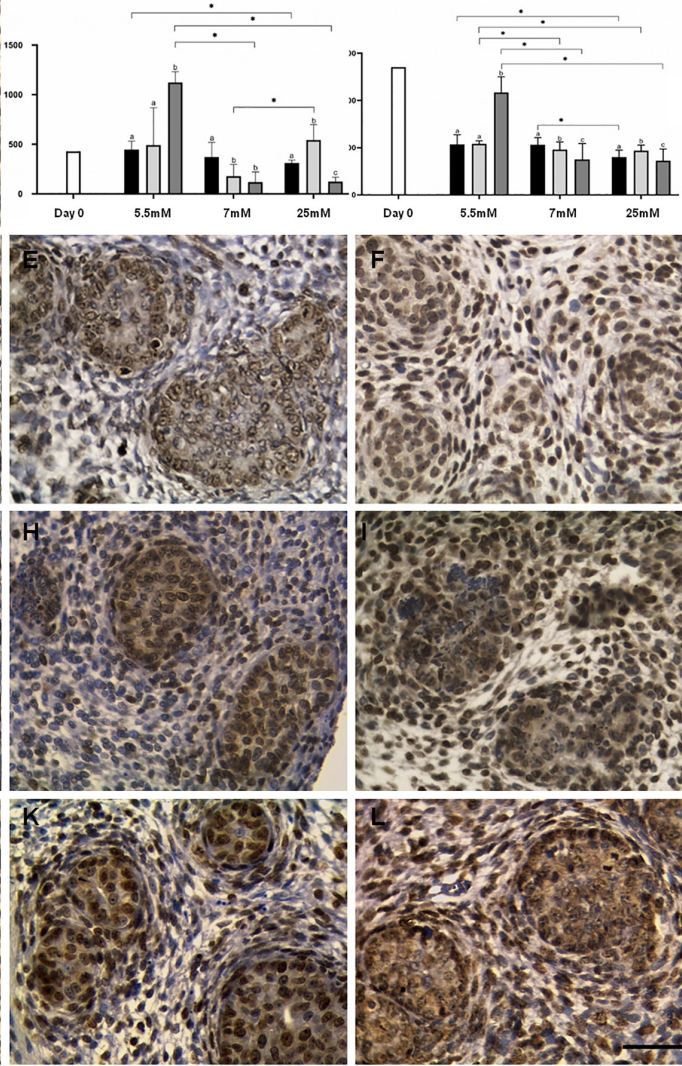

Day 2

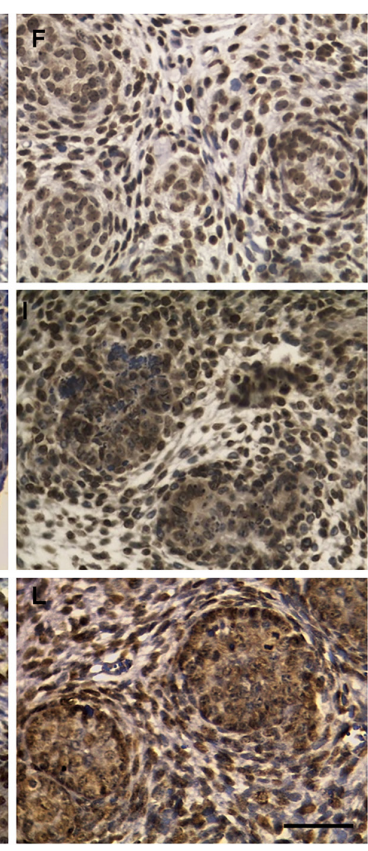

Day 3
Figure 3 Elevated glucose concentrations decreased cell proliferation during postnatal prostate development. (A, D-L) Representative images of immunohistochemistry for PCNA in histological sections of the rat prostate grown in DMEM media containing normal $(5.5 \mathrm{mM}$, D-F), moderate (7 mM, G-I) or high ( $25 \mathrm{mM}$, J-L) glucose concentration for 1,2 and 3 days after birth (Day 0, A). Proliferating cells are indicated by brown nuclear staining. Estimation of PCNA-positive cells at epithelium (B) and stromal (C) compartments showed decreased cell proliferation in prostates developed in glucose-rich environments. a,b $P<0.05$ for time exposure; $* P<0.05$ versus normal glucose group. Scale bar: $50 \mu \mathrm{m}$.
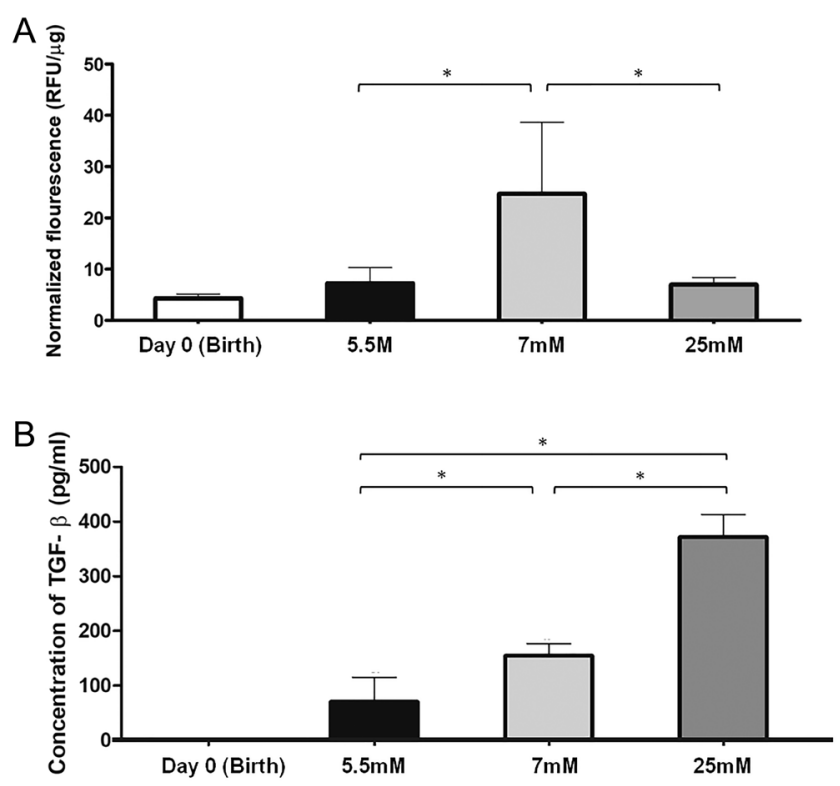

Figure 4 Effect of glucose-rich environment in prostate levels of active Caspase-3 (A) and TGF- $\beta$ (B). Rat prostate was grown in DMEM media containing normal $(5.5 \mathrm{mM})$, moderate $(7 \mathrm{mM})$ or high $(25 \mathrm{mM})$ glucose concentration during 3 days after birth (Day 0 ) $* P<0.05$ versus normal glucose group or different time exposure.

\section{Decreased cell proliferation is associated with reduced activation of ERK1/2 and increased expression of Wnt5a}

A part of the MAPK signaling pathway was evaluated if an inactivation of this signal could be associated to the impaired bud branching and cell proliferation found in the prostate after high glucose postnatal treatment. This analysis showed that the 7 and $25 \mathrm{mM}$ glucose treatments caused a reduction of ERK $1 / 2$ phosphorylation compared to the control. This drop of the signal activation was more expressive in the higher glucose group (Fig. 7A).

In addition, the expression of the Wnt5a gene was studied by real-time qPCR to elucidate another possible glucose mechanism in the control of cell proliferation. Figure 6B shows an increased expression of Wnt5a gene in the prostate of the $7 \mathrm{mM}$ glucose group, being 9 times higher if compared to the control (Fig. 7B).

\section{Discussion}

This investigation describes the morphological and biochemical changes induced by elevated glucose concentrations during the first postnatal days of rat prostate. The glucose concentrations chosen in this using Western blotting for ERK $1 / 2$ protein to determine 


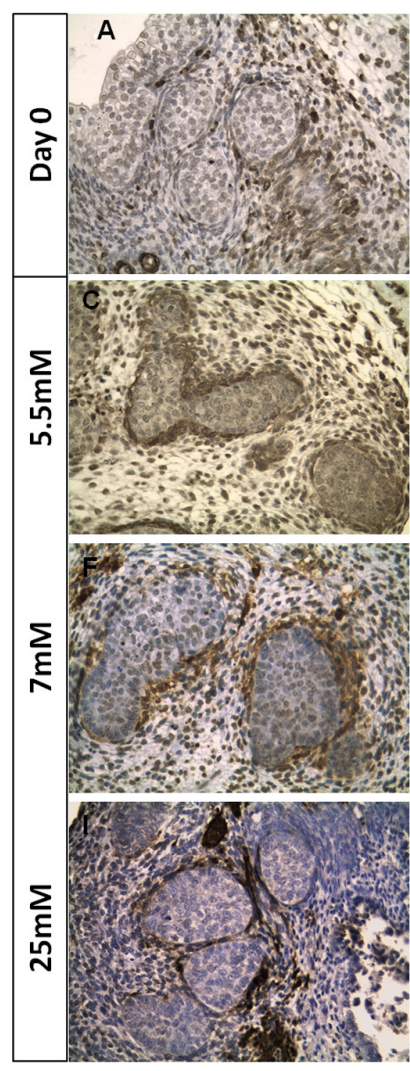

Day 1

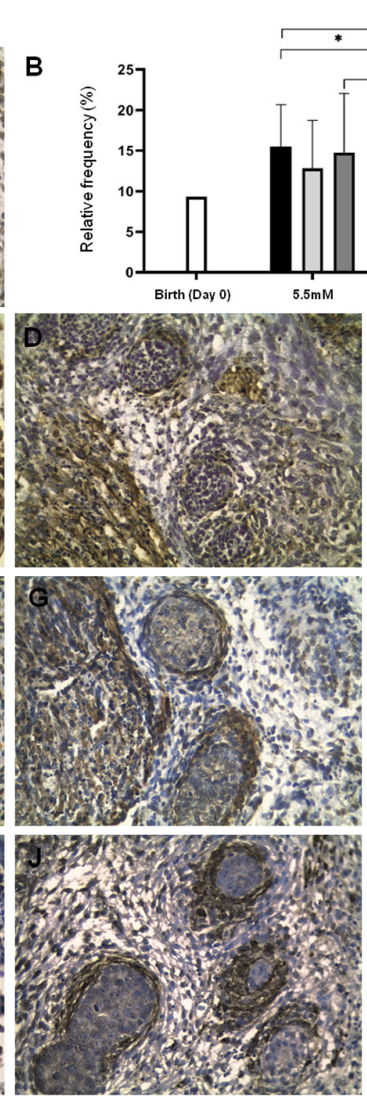

Day 2

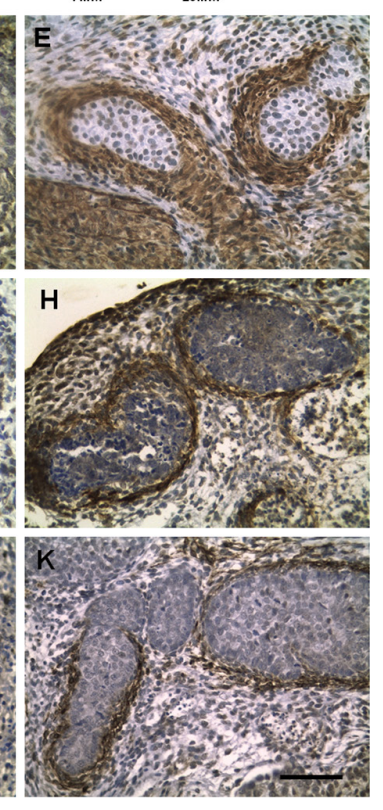

Day 3
Figure 5 Neonatal prostate smooth muscle cells are reduced after treatment with elevated glucose concentrations. (A, C-K) Representative images of immunohistochemistry for smooth muscle $\alpha$-actin in the rat prostate grown in DMEM media containing normal $(5.5 \mathrm{mM})$, moderate (7 $\mathrm{mM})$ or high $(25 \mathrm{mM})$ glucose concentration for 1, 2 and 3 days after birth (Day 0, A). Smooth muscle cells are indicated by brown staining at stromal compartment surrounding epithelial buds. (B) Graphical representation of the relative frequency $(\%)$ of smooth muscle $\alpha$-actin staining demonstrates the reduction of SMC frequency after glucose-rich treatments on the developing prostate. (C-E) The normal glucose group presents the SMC organized surrounding acinar buds in the stroma. $(\mathrm{F}-\mathrm{K})$ $7 \mathrm{mM}$ and $25 \mathrm{mM}$ treatments changed this arrangement and decreased the number of these cells. a,b $P<0.05$ for different time exposure or $* P<0.05$ versus normal glucose group. Scale bar: $50 \mu \mathrm{m}$. study were based on the normal glycemic levels found in humans $(5.5 \mathrm{mM}$, equivalent to $100 \mathrm{mg} / \mathrm{mL}$ ) and values above it that are considered non-physiological. A second criterion was based on glucose levels found in neonatal hyperglycemia (a commom condition of preterm newborns), as well as in the hyperglycemia of the offspring of obese mothers which is between 120$150 \mathrm{mg} / \mathrm{dL}(6.6-8 \mathrm{mM})$ or above. Thus, it was relevant to evaluate the initial events of prostate postnatal development in an environment whose glucose concentration is mild $(7 \mathrm{mM})$ or high $(25 \mathrm{mM})$, in relation to the normal blood glucose levels found in humans. The findings here described are novel and reveal important aspects of prostatic postnatal development and how it is affected by the glucose environment.

The prostate developmental features observed in vitro in the control group, such as the progressive increase in the number of acinar buds and the frequency of proliferating cells, are in accordance with those expected for the in vivo prostate development previously described (Cunha et al. 1987, Vilamaior et al. 2006). Their studies show that there is remarkable epithelial proliferation, ramification and canalization of the prostatic ducts after birth. This occurs at the same time as epithelial differentiation (Sugimura et al. 1986). The glucose-rich environments used in this study impaired normal prostate postnatal development since the reduction in cell proliferation and bud branching diverges with the postnatal processes mentioned previously for rat prostate. Studies on the effects of glucose in cell proliferation at the beginning of postnatal prostate development are virtually nonexistent. However, studies reporting the effect of diabetes on the adult prostate show a significant decrease in epithelial and stromal proliferation (Arcolino et al. 2010, Porto et al. 2011, Gobbo et al. 2012). Thus, for the first time and in a similar way, our data demonstrate that exposure to above normal concentrations of glucose by itself can impair prostate postnatal development, since optimal acinar budding will culminate in a structurally and functionally normal adult prostate.

The optimal prostate development depends on the cell proliferation. If cell proliferation and apoptosis occur at equivalent rates, as in normal and fully developed prostate tissue, there is no growth and gland ramification. However, if the rate of cell death exceeds that of proliferation, there is a progressive reduction in the gland volume, which is a common feature of castration-associated atrophy (Schalken 2005). It is well known that high glucose levels causes high oxidative stress to cells (Brownlee 2001), which can trigger DNA damage and endoplasmic reticulum stress, resulting in apoptosis (Wang et al. 2013, Grindel et al. 2016). Although apoptosis was only increased in the $7 \mathrm{mM}$ glucose group, the higher glucose one also showed a 


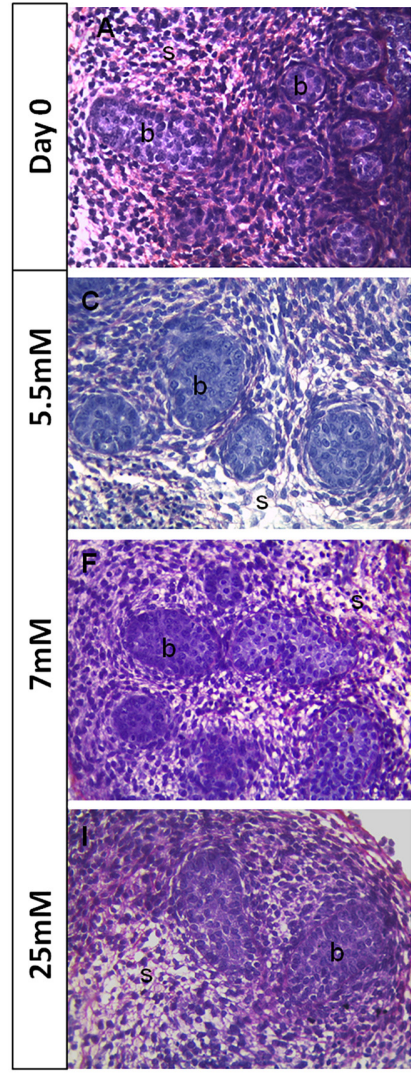

Day 1
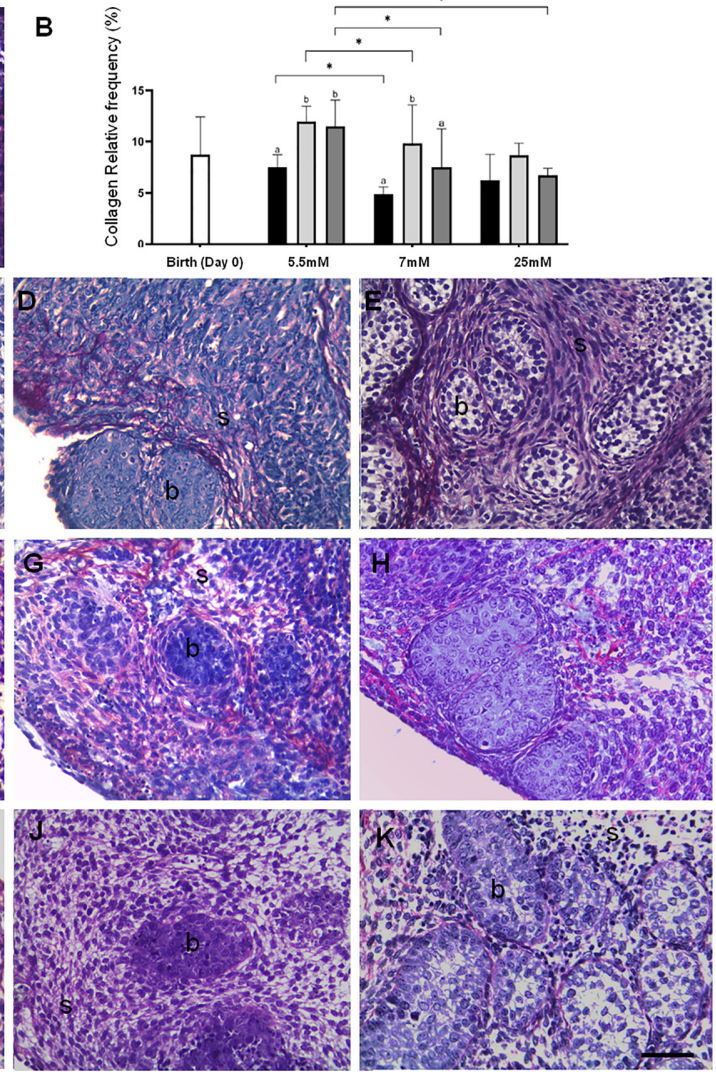

Day 2

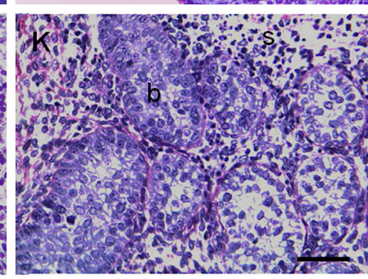

Day 3
Figure 6 Representative images of histological sections stained by picrosirius-hematoxylin of the rat prostate grown in DMEM media containing normal $(5.5 \mathrm{mM})$, moderate $(7 \mathrm{mM})$ or high ( $25 \mathrm{mM})$ glucose concentration for 1 , 2 and 3 days after birth (Day 0, A). Collagen fibers are indicated by pink staining ate stromal compartiment. (B) Graphical representation of the relative frequency (\%) of collagen staining. (C-E) In normal glucose concentration, a natural increase at collagen distribution can be noted from 1 to 3 days after birth. (F-K) There is a reduction in the collagen staining in the prostate developed under $7 \mathrm{mM}$ and $25 \mathrm{mM}$ glucose treatment. $\mathrm{a}, \mathrm{b} P<0.05$ for different time exposure or $* P<0.05$ versus normal glucose group. Scale bar: $50 \mu \mathrm{m}$. significant decrease in the number of acinar buds and cell proliferation. These findings may be an evidence of another type of cell death, such as necroptosis. This is similar to necrosis, but is highly regulated and occurs in environments in which the apoptosis mechanism is unfavorable (D'arcy 2019). The necroptosis process is given through the cytosolic interaction of proteins RIP1 and RIP3 with death receptors, such as the tumor necrosis factor-1 receptor (TNFR1) and Fas receptor. The activation of RIP1/3 leads to the inactivation of caspase- 8 and recruitment of the MLKL protein that promotes cell permeabilization and, ultimately, cell death (Wang et al. 2014). Liang et al. (2017) demonstrated that glucose in high concentrations causes injury in $\mathrm{H} 9 \mathrm{c} 2$ cardiac cells by increasing the expression of RIP3, suggesting necroptosis. Similarly, it has been shown that high concentrations of glucose induce necroptosis via RIP1/3 in podocytes from the glomerular filtration barrier $\mathrm{Xu}$ et al. 2019) and cardiomyocytes (Fang et al. 2019). Although this investigation has not evaluated specific markers for necroptosis, according to the literature, our results show that a cell death different from apoptosis is possible under higher glucose concentrations and may explain cell loss in the $25 \mathrm{mM}$ glucose group.

The reduction of cell proliferation in prostatic buds after glucose treatments may be, at least in part, related to the decrease in ERK1/2 activation, since this protein belongs to the MAPK family whose signaling pathway controls the cell cycle, survival and proliferation. Glucose, the major regulator of insulin production and release, activates nutrient-sensing and signal transduction pathways, including the mitogen-activated protein (MAP) kinases and extracellular signal-regulated protein kinases 1 and 2 (ERK1/2). There are in vitro studies indicating that high levels of glucose activate the ERK signaling pathway (Gibson et al. 2006, Zhu et al. 2012, Liu et al. 2016). However, the literature also shows that diabetes and high glucose environments can reduce phospho ERK1/2 levels in testis, skeletal muscle, pancreatic cells, fibroblast (Flores-Lopez et al. 2013, Donmez et al. 2014, Shamhart et al. 2014, Karpova et al. 2020). Kawano et al. (2001) pointed that such differences could be related to cell type-specific responses or to the fact that in these studies used higher concentrations of glucose $(55 \mathrm{mM})$. Additionally, a possible explanation for this unexpected result could be related to an inhibition of the insulin receptor (IR) pathway. Although we have not evaluated this pathway, other authors have already demonstrated this downregulatory effect of glucose on IR itself and the downstream pathway. Accordingly, Buren et al. (2003) demonstrated in adipocytes that glucose above $15 \mathrm{mM}$ reduces the expression of IRS1. Moreover, other researchers demonstrated reduced expression and phosphorylation of IR and IRS-1 in 

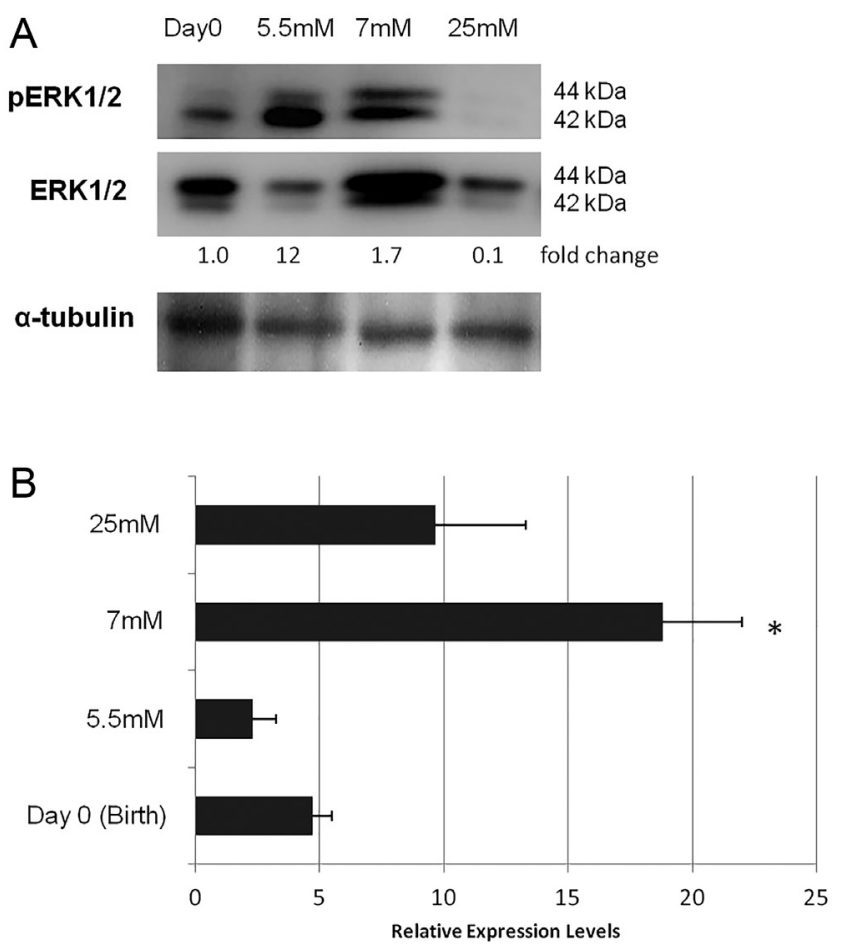

Figure 7 Prostate grown under elevated glucose environment inactivated ERK1/2 signaling pathway as well as increased Wnt5a expression. Rat prostate was grwn in DMEM media containing normal $-5.5 \mathrm{mM}$, moderate $(7 \mathrm{mM})$ or high $(25 \mathrm{mM})$ glucose concentrations during 3 days after birth (Day 0). (A) Western blotting analysis of ERK $1 / 2$ in its normal and phosphorylated forms demonstrated a reduction of ERK1/2 phosphorylation after high glucose treatment. (B) RT-qPCR analysis showed that $7 \mathrm{mM}$ treatment increased Wnt5a mRNA expression in prostates on postnatal day 3 . ${ }^{*} P<0.05$ versus normal glucose group.

glomerulus in vivo and in vitro and also in HUVECs endothelial cells (De Nigris et al. 2015, Katsoulieris et al. 2016). Activation of IR causes its autophosphorylation, leading to the recruitment and phosphorylation of receptor substrates such as IRS and Shc proteins, the latter being an activator of the Ras-ERK pathway. Thus, it is possible that a high-glucose environment during prostate postnatal development may have decreased IR pathway, resulting in reduced ERK1/2 levels. Regardless of its origin, based on our findings, we suggest that the decreased activation of ERK1/2 caused by a high glucose environment may have a negative impact on prostate branching by reducing cell proliferation.

Another significant prostate change caused by elevated glucose environments was the reduction in the amount of smooth muscle $\alpha$-actin which may be a consequence of decreased cell number, since cell proliferation has also reduced in the stromal compartment. The deleterious effect of glucose-rich environment on these cells was observed by Peiró et al. (2001), who reported a $20 \%$ decrease in the number of viable human aorta SMC grown under a high glucose concentration. It has been suggested that this response may be a result of cell death induced by oxidative stress or by the delay in glucose-induced cell growth. During prostate development, SMC are essential for inducing proliferation of the secretory epithelium, through epithelium-stroma interaction (Cunha 2008). Neither the epithelium nor the stroma are able to develop in the absence of each other (Cunha et al. 1996, Hayward \& Cunha 2000). At adulthood, under normal conditions, besides its contractile function, these cells are involved in the organ homeostasis by regulating the adjacent epithelial cells through androgen-dependent paracrine signaling (Peinetti et al. 2018). We cannot predict the long-term effect of a glucose-rich environment on prostate postnatal development, since the methodology employed in this investigation does not allow longer than few days of experimental period. However, if this reduction on SMC is maintained in vivo, it is not difficult to note that there will be an impact on the stromalepithelium interaction affecting the entire formation of the gland. Considering the importance of the SMC, this effect may have an impact on reproductive function later in adult life, such as impaired secretion (if the epithelium does not have adequate stromal stimulus for differentiation) and also in the gland contraction if the fibromuscular stroma is not reestablished. In this scenario, both the secretory activity and secretion release may be a problematic condition caused by highglucose environment at postnatal prostate development.

Regarding the effect of glucose-rich environments on the extracellular matrix of the developing prostate, there was a significant reduction in the distribution of collagen associated with increased levels of TGF$\beta$. These data reflect a change in the homeostatic state of the gland subjected to high concentrations of glucose. Fibroblasts are the main cell of the prostate stroma, where they synthesize molecules that not only provide a structural gland support, but also signals which are essential to prostate homeostasis (Aumüller \& Seitz 1990, Cunha et al. 2004). Thus, the collagen reduction in the initial postnatal prostate development implies in gland structural damage. The decreased cell proliferation on the stromal compartment, besides affecting smooth muscle cells, also impacts fibroblast content, thereby impairing collagen synthesis. Although TGF- $\beta$ was elevated and presents a pro-fibrotic activity, it did not induce collagen deposition. Singh et al. (2001) reported that elevated glucose concentrations inhibit MMP-2 activity in mesangial cells and stimulate expression of the metalloproteinase- 2 tissue inhibitor (TIMP2). In fact, a key function performed by TGF- $\beta$ is suppressing the degradation of the extracellular matrix by inhibiting the synthesis of MMPs (Javelaud \& Mauviel 2004). It is therefore clear that high concentrations of glucose induced major changes in the stromal 
compartment, altering the gland structure by decreasing collagen deposition.

WNT/ $\beta$-catenin signaling is an evolutionarily conserved pathway that plays a role in cellular proliferation, differentiation, and migration in multiple organ systems (Pak et al. 2019). The Wnt member 5a (Wnt5a) gene is one of the most highly investigated Wnts and has been implicated in almost all aspects of non-canonical WNT signaling (Wang et al. 2019). Wnt5a was found to be indispensable during the urogenital sinus development and is also highly expressed at the distal tips and along the centro-distal periductal mesenchyme during the period of prostate postnatal branching morphogenesis (Huang et al. 2009). Additionally, Allgeier et al. (2008) demonstrated that loss of Wnt5a impeded bud branching during morphogenesis. According to Wang et al. (2008), the requirement for WNT signaling, both canonical and non-canonical, in prostate branching morphogenesis is tightly and delicately regulated as both increased and decreased WNT activity could adversely affect prostate branching morphogenesis in ex vivo cultures. Those studies highlight the importance of Wnt5a in postnatal prostate development.

It is reasonable to suppose that, besides ERK 1/2 signaling inactivation, the decreased cell proliferation would be related also to upregulation of Wnt5a caused by glucose-rich environments. This could be due to its inhibitory effect on the canonical WNT pathway, which presents proliferative effects; this antagonist role was already shown by Baarsma and Königshoff (2013) in lung epithelial cells. Additionally, Peng et al. (2011) demonstrated that WNT5A has an antiproliferative effect on placental choriocarcinoma (JAR) cells, antagonizes canonical signaling and reduces the growth of xenographic tumors. The role of WNT5a in cell proliferation is complex and is highly dependent on cell type. Some researchers show a promoter effect in glioblastoma and pancreatic cancer and others an inhibitory role in B cells and in colorectal cancer (Peng et al. 2011). In this scenario, WNT5a has been shown to act as a tumor suppressor in several types of cancer, including breast, prostate and colon cancer, since it inhibits proliferation and stimulates apoptosis in vivo and in vitro (Thiele et al. 2015, Patel et al. 2019). These results about the antiproliferative effect caused by high glucose in the prostate postnatal development, possibly related to alterations of ERK $1 / 2$ and Wnt5a, are summarized in Fig. 8.

Data from this investigation demonstrate that an high-glucose environment during the first postnatal days has a negative impact on molecular mechanisms that govern cell proliferation such as ERK1/2 and Wnt5a, which interferes with prostate branching morphogenesis. This impaired prostate branching may limit the optimal glandular development and influence its secretory activity during adulthood. The inhibitory effect on cell proliferation also impacts on stroma cells, affecting smooth muscle organization and collagen deposition. Besides altering the epithelium-stroma interaction, these changes will impair structural support for acinar buds during branching, as well as affecting contractile capacity, which is fundamental to glandular reproductive function. Thus, since the postnatal period is of major importance for prostate development, an ideal neonatal glycemic condition is necessary during this period so that glands can achieve an optimal tissue arrangement that allows the male reproductive function in adulthood.

\section{Prostate Postnatal Development}

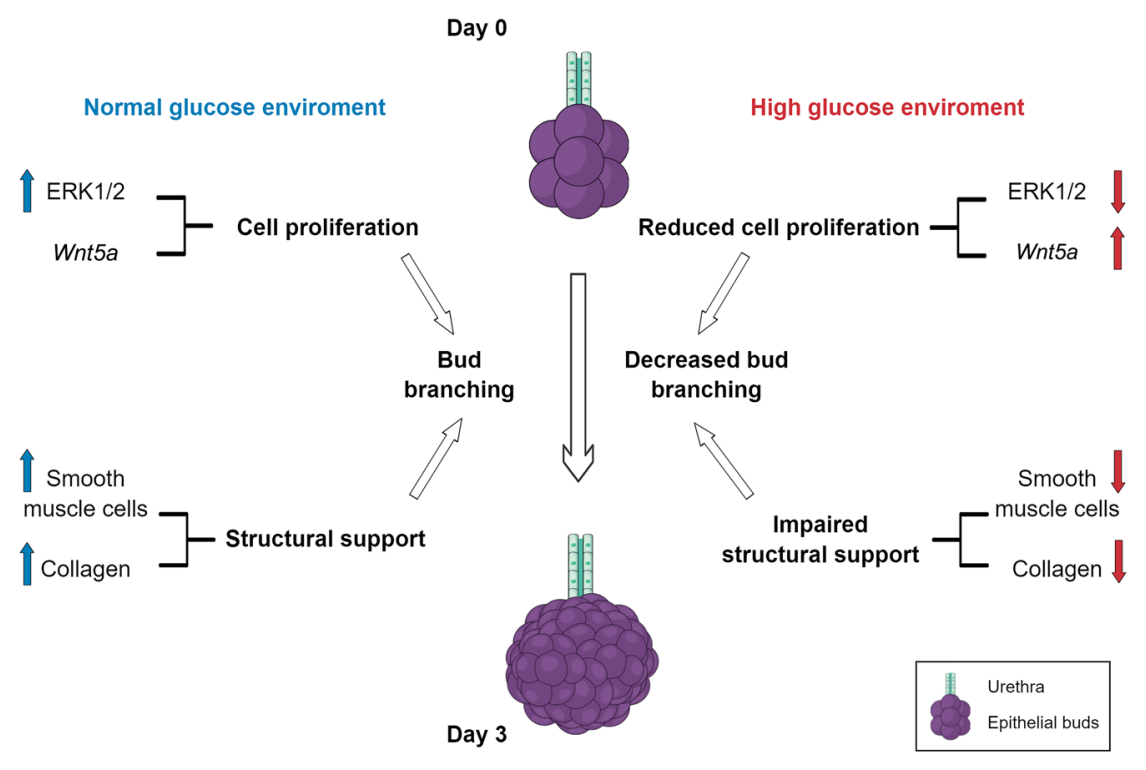

Figure 8 Hypothetical model for the prostate branching impairment after high-glucose environment during the first postnatal days. Cell proliferation and stromal support are important elements for the epithelial budding process. High-glucose environment inactivates ERK $1 / 2$ signaling pathway and upregulates Wnt5a expression causing a reduction on cell proliferation. In the stromal compartiment, high glucose decreases smooth muscle cells and collagen deposition, altering structural support for epithelial budding. All this changes culminates in an impaired prostate branching. 


\section{Declaration of interest}

The authors declare that there is no conflict of interest that could be perceived as prejudicing the impartiality of the research reported.

\section{Funding}

FAPEMIG-Minas Gerais Research Funding Foundation; Grant number: APQ-02645-15.

\section{Author contribution statement}

I S C performed experiments, analysed data and wrote the paper. A R C, B P B, L C M performed experiments and analysed data. J R C S, P T F, C U V, performed RT-qPCR and data analysis. R G Z performed whole tissue culture. D L R conceived the study and wrote the paper.

\section{Acknowledgements}

The authors are grateful for the technical assistance of Fabricio Faria Araujo and Ester Cristina Borges Araujo.

\section{References}

Allgeier SH, Lin TM, Vezina CM, Moore RW, Fritz WA, Chiu SY, Zhang C \& Peterson RE 2008 Wnt5a selectively inhibits mouse ventral prostate development. Developmental Biology 324 10-17. (https://doi. org/10.1016/j.ydbio.2008.08.018)

Arcolino FO, Ribeiro DL, Gobbo MG, Taboga SR \& Góes RM 2010 Proliferation and apoptotic rates and increased frequency of p63-positive cells in the prostate acinar epithelium of alloxan-induced diabetic rats. International Journal of Experimental Pathology 91 144-154. (https://doi. org/10.1111/j.1365-2613.2009.00696.x)

Aumüller G \& Seitz J 1990 Protein secretion and secretory processes in male accessory sex glands. Internacional Review of Cytology 1 127-231. (https://doi.org/10.1016/S0074-7696(08)60660-9)

Baarsma H \& Königshoff M 2013 WNT5A antagonizes canonical WNT/Bcatenin signaling in lung epithelial cells. European Respiratory Journal 42 P4893.

Bradford MM 1976 Rapid and sensitive method for the quantitation of microgram quantities of protein utilizing the principle of protein-dye binding. Analytical Biochemistry 72 248-254.

Brownlee M 2001 Biochemistry and molecular cell biology of diabetic complications. Nature 414 813-820. (https://doi.org/10.1038/414813a)

Bruni-Cardoso A \& Carvalho HF 2007 Dynamics of the epithelium during canalization of the rat ventral prostate. Anatomical Record 290 1223-1232. (https://doi.org/10.1002/ar.20591)

Bruni-Cardoso A, Vilamaior PS, Taboga SR \& Carvalho HF 2008 Localized matrix metalloproteinase (MMP)-2 and MMP-9 activity in the rat ventral prostate during the first week of postnatal development. Histochemistry and Cell Biology 129 805-815. (https://doi.org/10.1007/s00418-008-0407-x)

Burén J, Liu HX, Lauritz J \& Eriksson JW 2003 High glucose and insulin in combination cause insulin receptor substrate- 1 and -2 depletion and protein kinase $\mathrm{B}$ desensitisation in primary cultured rat adipocytes: possible implications for insulin resistance in type 2 diabetes. European Journal of Endocrinology 148 157-167. (https://doi.org/10.1530/ eje.0.1480157)

Cunha GR, Donjacour AA, Cooke PS, Mee S, Bigsby RM, Higgins SJ \& Sugimura Y 1987 The endocrinology and developmental biology of the prostate. Endocrine Reviews 8 338-362. (https://doi.org/10.1210/edrv8-3-338)

Cunha GR, Hayward SW, Dahiya R \& Foster BA 1996 Smooth muscleepithelial interactions in normal and neoplastic prostatic development. Acta Anatomica 155 63-72. (https://doi.org/10.1159/000147791)
Cunha GR, Cooke PS \& Kurita T 2004 Role of stromal-epithelial interactions in hormonal responses. Archives of Histology and Cytology 67 417-434. (https://doi.org/10.1679/aohc.67.417)

Cunha GR 2008 Mesenchymal-epithelial interactions: past, present, and future. Differentiation 76 578-586. (https://doi.org/10.1111/j.14320436.2008.00290.x)

Cunha GR, Vezina CM, Isaacson D, Ricke WA, Timms BG, Cao M, Franco O \& Baskin LS 2018 Development of the human prostate. Differentiation 103 24-45. (https://doi.org/10.1016/j.diff.2018.08.005)

D'arcy MS 2019 Cell death: a review of the major forms of apoptosis, necrosis and autophagy. Cell Biology International 43 582-592. (https:// doi.org/10.1002/cbin.11137)

Damasceno AA, Carvalho CP, Santos EM, Botelho FV, Araújo FA, Deconte SR, Tomiosso TC, Balbi AP, Zanon RG, Taboga SR et al. 2014 Effects of maternal diabetes on male offspring: high cell proliferation and increased activity of MMP-2 in the ventral prostate. Cell and Tissue Research 358 257-269. (https://doi.org/10.1007/s00441-014-1941-6)

De Nigris V, Pujadas G, La Sala L, Testa R, Genovese S \& Ceriello A 2015 Short-term high glucose exposure impairs insulin signaling in endothelial cells. Cardiovascular Diabetology 14 114. (https://doi.org/10.1186/ s12933-015-0278-0)

Donmez YB, Kizilay G \& Topcu-Tarladacalisir Y 2014 MAPK immunoreactivity in streptozotocin-induced diabetic rat testis. Acta Cirurgica Brasileira 29 644-650. (https://doi.org/10.1590/S0102-8650201400160004)

Fang TT, Cao RP, Ye HW, Ma SF \& Gao Q 2019 Effects of high glucose induced primary cardiomyocytes injury on necroptosis and the related mechanism. Chinese Journal of Applied Physiology 2 160-164. (https:// doi.org/10.12047/j.cjap.5710.2019.035)

Flores-López LA, Díaz-Flores M, García-Macedo R, Ávalos-Rodríguez A, Vergara-Onofre $M$, Cruz $M$, Contreras-Ramos A, Konigsberg $M$ \& Ortega-Camarillo C 2013 High glucose induces mitochondrial p53 phosphorylation by p38 MAPK in pancreatic RINm5F cells. Molecular Biology Reports 40 4947-4958. (https://doi.org/10.1007/s11033-0132595-2)

Gibson TB, Lawrence MC, Gibson CJ, Vanderbilt CA, McGlynn K, Arnette D, Chen W, Collins J, Naziruddin B, Levy MF et al. 2006 Inhibition of glucose-stimulated activation of extracellular signal regulated protein kinases 1 and 2 by epinephrine in pancreatic beta-cells. Diabetes $\mathbf{5 5}$ 1066-1073. (https://doi.org/10.2337/diabetes.55.04.06.db05-1266)

Gobbo MG, Taboga SR, Ribeiro DL \& Góes RM 2012 Short-term stromal alterations in the rat ventral prostate following alloxan-induced diabetes and the influence of insulin replacement. Micron 43 326-333. (https:// doi.org/10.1016/j.micron.2011.09.009)

Grindel A, Guggenberger B, Eichberger L, Pöppelmeyer C, Gschaider M, Tosevska A, Mare G, Briskey D, Brath H \& Wagner KH. 2016 Oxidative stress, DNA damage and DNA repair in female patients with diabetes mellitus type 2. PLOS ONE 11 e0162082. (https://doi.org/10.1371/ journal.pone.0162082)

Hayward SW \& Cunha GR 2000 The prostate: development and physiology. Radiologic Clinics of North America 1 1-14. (https://doi.org/10.1016/ S0033-8389(05)70146-9)

Huang L, Pu Y, Hu WY, Birch L, Luccio-Camelo D, Yamaguchi T \& Prins GS 2009 The role of Wnt5a in prostate gland development. Developmental Biology 328 188-199. (https://doi.org/10.1016/j.ydbio.2009.01.003)

Javelaud D \& Mauviel A 2004 Mammalian transforming growth factor- $\beta$ s: smad signaling and physio-pathological roles. International Journal of Biochemistry and Cell Biology 36 1161-1165. (https://doi.org/10.1016/ S1357-2725(03)00255-3)

Katsoulieris EN, Drossopoulou GI, Kotsopoulou ES, Vlahakos DV, Lianos EA \& Tsilibary EC 2016 High glucose impairs insulin signaling in the glomerulus: an in vitro and ex vivo approach. PLOS ONE $\mathbf{1 1}$ e0158873. (https://doi.org/10.1371/journal.pone.0158873)

Karpova T, de Oliveira AA, Naas H, Priviero F \& Nunes KP 2020 Blockade of Toll-like receptor 4 (TLR4) reduces oxidative stress and restores phospho-ERK $1 / 2$ levels in Leydig cells exposed to high glucose. Life Sciences 27 117365. (https://doi.org/10.1016/j.Ifs.2020.117365)

Kawano Y, Ryder JW, Rincon J, Zierath JR, Krook A \& WallbergHenriksson H 2001 Evidence against high glucose as a mediator of ERK1/2 or p38 MAPK phosphorylation in rat skeletal muscle. American Journal of Physiology: Endocrinology and Metabolism 281 E1255E1259. (https://doi.org/10.1152/ajpendo.2001.281.6.e1255)

Korsmo HW, Edwards K, Dave B, Jack-Roberts C, Yu H, Saxena A, Salvador M, Dembitzer M, Phagoora J \& Jiang X 2020 Prenatal choline 
supplementation during high-fat feeding improves long-term blood glucose control in male mouse offspring. Nutrients 12 E144. (https://doi. org/10.3390/nu12010144)

Liang W, Chen M, Zheng D, He J, Song M, Mo L, Feng J \& Lan J 2017 A novel damage mechanism: contribution of the interaction between necroptosis and ROS to high glucose-induced injury and inflammation in $\mathrm{H} 9 \mathrm{c} 2$ cardiac cells. Internacional Journal of Molecular Medicine $\mathbf{4 0}$ 201-208. (https://doi.org/10.3892/ijmm.2017.3006)

Liu D, Liang X \& Zhang H 2016 Effects of high glucose on cell viability and differentiation in primary cultured schwann cells: potential role of ERK signaling pathway. Neurochemical Research 41 1281-1290. (https://doi. org/10.1007/s11064-015-1824-6)

Livak KJ \& Schmittgen TD 2001 Analysis of relative gene expression data using real-time quantitative PCR and the 2(-Delta Delta C(T)) method. Methods 25 402-408. (https://doi.org/10.1006/meth.2001.1262)

Lopes ER, Foster BA, Donjacour AA \& Cunha GR 1996 Initiation of secretory activity of rat prostatic epithelium in organ culture. Endocrinology 137 4225-4234. (https://doi.org/10.1210/endo.137.10.8828481)

Pak S, Park S, Kim Y, Park JH, Park CH, Lee KJ, Kim CS \& Ahn H 2019 The small molecule WNT/ $\beta$-catenin inhibitor CWP232291 blocks the growth of castration-resistant prostate cancer by activating the endoplasmic reticulum stress pathway. Journal of Experimental and Clinical Cancer Research 38 342. (https://doi.org/10.1186/s13046-019-1342-5)

Patel R, Brzezinska EA, Repiscak P, Ahmad I, Mui E, Gao M, Blomme A, Harle V, Tan EH \& Malviya G et al. 2019 Activation of $\beta$-catenin cooperates with loss of pten to drive AR-independent castrationresistant prostate cancer. Cancer Research 80 576-590. (https://doi. org/10.1158/0008-5472.CAN-19-1684)

Peinetti N, Scalerandi MV, Cuello Rubio MM, Leimgruber C, Nicola JP, Torres AI, Quintar AA \& Maldonado CA 2018 The response of prostate smooth muscle cells to testosterone is determined by the subcellular distribution of the androgen receptor. Endocrinology 159 945-956. (https://doi.org/10.1210/en.2017-00718)

Peiró C, Lafuente N, Matesanz N, Cercas E, Llergo JL, Vallejo S, RodríguezMañas L \& Sánchez-Ferrer CF 2001 High glucose induces cell death of cultured human aortic smooth muscle cells through the formation of hydrogen peroxide. British Journal of Pharmacology 133 967-974. (https://dx.doi.org/10.1038\%2Fsj.bjp.0704184)

Peng S, Zhang J, Chen J \& Wang H 2011 Effects of Wnt5a on proliferation and apoptosis in JAR choriocarcinoma cells. Molecular Medicine Report 4 99-104. (https://doi.org/10.3892/mmr.2010.383)

Pinto-Fochi ME, Pytlowanciv EZ, Reame V, Rafacho A, Ribeiro DL, Taboga SR \& Góes RM 2016 A high-fat diet fed during different periods of life impairs steroidogenesis of rat Leydig cells. Reproduction 152 795-808. (https://doi.org/10.1530/REP-16-0072)

Porto EM, Dos Santos SA, Ribeiro LM, Lacorte LM, Rinaldi JC, Justulin Jr LA \& Felisbino SL 2011 Lobe variation effects of experimental diabetes and insulin replacement on rat prostate. Microscopy Research and Technique 74 1040-1048. (https://doi.org/10.1002/jemt.20991)

Poston L, Caleyachetty R, Cnattingius S, Corvalán C, Uauy R, Herring S \& Gillman MW 2016 Preconceptional and maternal obesity: epidemiology and health consequences. Lancet Diabetes Endocrinology 4 1025-1036. (https://doi.org/10.1016/S2213-8587(16)30217-0)

Pytlowanciv EZ, Pinto-Fochi ME, Reame V, Gobbo MG, Ribeiro DL, Taboga SR \& Góes RM 2016 Differential ontogenetic exposure to obesogenic environment induces hyperproliferative status and nuclear receptors imbalance in the rat prostate at adulthood. Prostate $\mathbf{7 6}$ 662-678. (https://doi.org/10.1002/pros.23158)

Ribeiro DL, Taboga SR \& Góes RM 2009 Diabetes induces stromal remodelling and increase in chondroitin sulphate proteoglycans of the rat ventral prostate. International Journal of Experimental Pathology 90 400-411. (https://doi.org/10.1111/j.1365-2613.2009.00657.x)

Ribeiro DL, Pinto ME, Rafacho A, Bosqueiro JR, Maeda SY, AnselmoFranci JA, Taboga SR \& Góes RM 2012 High-fat diet obesity associated with insulin resistance increases cell proliferation, estrogen receptor, and Pi3K proteins in rat ventral prostate. Journal of Andrology 33 854-865. (https://doi.org/10.2164/jandrol.111.016089)

Rozance PJ \& Hay WW 2010 Neonatal hyperglycemia. NeoReviews 11 e632-e639. (https://doi.org/10.1542/neo.11-11-e632)

Ramel S \& Rao R 2020 Hyperglycemia in extremely preterm infants. NeoReviews 21 e89-e97. (https://doi.org/10.1542/neo.21-2-e89)
Schalken J 2005 Androgen receptor mediated growth of prostate (cancer). European Urology Supplements 4 4-11. (https://doi.org/10.1016/j. eursup.2005.08.006)

Shamhart PE, Luther DJ, Adapala RK, Bryant JE, Petersen KA, Meszaros JG \& Thodeti CK 2014 Hyperglycemia enhances function and differentiation of adult rat cardiac fibroblasts. Canadian Journal of Physiology and Pharmacology 92 598-604. (https://doi.org/10.1139/cjpp-2013-0490)

Şimşek DG, Ecevit A, Hatipoğlu N, Çoban A, Arısoy AE, Baş F, Mutlu GY, Bideci A \& Özek E 2018 Neonatal hyperglycemia, which threshold value, diagnostic approach and treatment?: Turkish neonatal and pediatric endocrinology and diabetes societies consensus report. Turk Pediatri Arsivi 53 (Supplement 1) S234-S238. (https://doi.org/10.5152/ TurkPediatriArs.2018.01821)

Singh R, Song RH, Alavi N, Pegoraro AA, Singh AK \& Leehey DJ 2001 High glucose decreases matrix metalloproteinase-2 activity in rat mesangial cells via transforming growth factor- $\beta 1$. Nephron Experimental Nephrology 9 249-257. (https://doi.org/10.1159/000052619)

Sugimura Y, Cunha GR \& Donjacour AA 1986 Morphogenesis of ductal networks in the mouse prostate. Biology of Reproduction 34 961-971. (https://doi.org/10.1095/biolreprod34.5.961)

Thiele S, Göbel A, Rachner TD, Fuessel S, Froehner M, Muders MH, Baretton GB, Bernhardt R, Jakob F, Glüer CC et al. 2015 Wnt5A has anti-prostate cancer effects in vitro and reduces tumor growth in the skeleton in vivo. Journal of Bone and Mineral Research 30 471-480. (https://doi.org/10.1002/jbmr.2362)

Vilamaior PS, Taboga SR \& Carvalho HF 2006 Postnatal growth of the ventral prostate in winstar rats: a stereological and morphometrical study. Anatomical Record Part A 288 885-892. (https://doi.org/10.1002/ ar.a.20363)

Wang BE, Wang XD, Ernst JA, Polakis P \& Gao WQ 2008 Regulation of epithelial branching morphogenesis and cancer cell growth of the prostate by wnt signaling. PLOS ONE 3 e2186. (https://doi.org/10.1371/ journal.pone.0002186)

Wang F, Reece EA \& Yang P 2013 Superoxide dismutase 1 overexpression in mice abolishes maternal diabetes - induced endoplasmic reticulum stress in diabetic embryopathy. American Journal of Obstetrics and Gynecology 209 345.e1-345.e7. (https://doi.org/10.1016/j. ajog.2013.06.037)

Wang H, Sun L, Su L, Rizo J, Liu L, Wang LF, Wang FS \& Wang X 2014 Mixed lineage kinase domain-like protein mlkl causes necrotic membrane disruption upon phosphorylation by RIP3. Molecular Cell 54 133-146. (https://doi.org/10.1016/j.molcel.2014.03.003)

Wang T, Liu X \& Wang J 2019 Upregulation of Wnt5a inhibits proliferation and migration of hepatocellular carcinoma cells. Journal of Cancer Research and Therapeutics 15 904-908. (https://doi.org/10.4103/jcrt.JCRT_886_18)

Weibel ER 1974 Selection of the best method in stereology. Journal of Microscopy 100 261-269. (https://doi.org/10.1111/j.1365-2818.1974. tb03938.x)

Xu Y, Gao H, Hu Y, Fang Y, Qi C, Huang J, Cai X, Wu H, Ding X \& Zhang Z 2019 High glucose-induced apoptosis and necroptosis in podocytes is regulated by UCHL1 via RIPK1/RIPK3 pathway. Experimental Cell Research 382 111463. (https://doi.org/10.1016/j.yexcr.2019.06.008)

Zhu H, Yu WJ, Le Y, Wang WJ, Li F, Gui T, Wang YM, Shi WD, Ding WL \& Fan XQ 2012 High glucose levels increase the expression of neurotrophic factors associated with p-p42/p44 MAPK in Schwann cells in vitro. Molecular Medicine Reports 6 179-184. (https://doi. org/10.1007/BF03402113)

Zamir I, Tornevi A, Abrahamsson T, Ahlsson F, Engström E, Hallberg B, Hansen-Pupp I, Stoltz Sjöström E \& Domellöf M 2018 Hyperglycemia in extremely preterm infants - insulin treatment, mortality and nutrient intakes. Journal of Pediatrics 200 104.e1-110.e1. (https://doi. org/10.1016/j.jpeds.2018.03.049)

Received 14 February 2020

First decision 14 April 2020

Revised manuscript received 12 May 2020

Accepted 5 June 2020 